Skinner, H. H. \& Bradish, C. J. (1954). J. gen. Microbiol. 10, 377-397.

\title{
Exposure to Light as a source of Error in the Estimation of the Infectivity of Virus Suspensions
}

\author{
BY H. H. SKINNER AND C. J. BRADISH \\ Research Institute (Animal Virus Diseases), Pirbright, Surrey
}

\begin{abstract}
SUMMARY : Experiments were made to determine whether the infectivity of virus suspensions was influenced by exposure to daylight of normal laboratory intensity or by exposure to artificial light. The infectivity of dilutions of virus suspensions held in bottles or cells was determined after exposure to light under a variety of conditions; the influence of exposure was indicated by comparison with the infectivity of control suspensions kept in darkness. The infectivity titres indicated by serial dilutions, in phosphate saline, of unfiltered fresh suspensions of egg strains of the viruses of vesicular stomatitis, influenza, Newcastle disease and fowl-plague following exposure to daylight for $4 \mathrm{hr}$. were 3-5 logarithmic units lower than those indicated by the dark controls. Changes of this magnitude suggest that with these virus strains significant errors might arise in infectivity titrations if suspensions were exposed to light for much shorter periods. Inactivation due to exposure to daylight was demonstrated in similar experiments with an egg strain of vaccinia virus, a mouse neurotropic strain of influenza virus and with guinea-pig strains and mouse neurotropic strains of the virus of vesicular stomatitis. Results of experiments with the virus of vesicular stomatitis indicated that inactivation by exposure to light may be eliminated almost completely by the inclusion of $10 \%$ rabbit serum in the suspending medium. Losses of infectivity increased with the intensity of illumination and with the duration of exposure. Filtration or storage of certain initial materials also increased the susceptibility to inactivation of virus suspensions derived from them. The infectivity of suspensions of the virus of foot-and-mouth disease, even after filtration, was relatively stable during exposure to light.
\end{abstract}

During the course of infectivity titrations designed to determine the regularity of response of chick embryos to the inoculation of fourfold dilutions of an egg strain (Ind. C) of vesicular stomatitis virus, it was observed on one occasion that the infection rate was unexpectedly low for the two lowest dilutions when their inoculation was delayed for 30-100 min. longer than usual. In two further titrations with the same egg strain dilutions containing originally 25 and 80 ID 50 were no longer infective when re-inoculated after an interval of $3 \mathrm{hr}$.

The standard procedure for infectivity titrations at that time (July 1947) was to prepare dilutions of virus suspensions in screw-capped bottles and to leave these on the laboratory bench whilst eggs were being prepared for inoculation of the chorioallantoic membranes. Groups of 6 eggs were inoculated with each dilution, beginning with the highest, the inoculation being made as each membrane was dropped. One egg was inoculated every minute, and at least $30 \mathrm{~min}$. were required to complete the inoculation of a series of five dilutions.

In view of the demonstration of the instability of the infectivity of suspensions of this strain of virus a new procedure for infectivity titration was adopted thenceforth in which the eggs were prepared first. The virus sus- 
pension was then diluted serially and the dilutions inoculated immediately into the prepared eggs at the rate of about 6 per min. Using this rapid procedure it was found that the infectivity titre indicated by a series of dilutions was higher by more than one logarithmic unit than when inoculation was repeated after the same dilutions had been stored for $1 \mathrm{hr}$. on the laboratory bench at room temperature or in iced water. This difference was due to the complete loss of the infectivity of the highest dilutions. Similar results were obtained whether dilutions were prepared in Hartley's digest broth, saline, or phosphate saline $(\mathrm{pH} 7 \cdot 6)$. Inactivation was slight, however, when dilutions were stored in the dark for prolonged periods.

It was concluded, therefore, that exposure to daylight was a major factor in the mechanism of the reduction of infectivity. It was evident that in many normal procedures for infectivity titrations the influence of exposure to light might remain undetected and could be the cause of serious errors if suitable precautions were not adopted. The subject of the present paper is a comparative study of the influence of exposure to light on the infectivity of suspensions of the viruses of vesicular stomatitis and some other diseases.

\section{METHODS}

\section{Virus strains and test animals employed}

Foot-and-mouth disease virus. Guinea-pig adapted virus of the following strains (immunological types) was used: strain 1 (Vallée O); ASJ (Vallée O); GB (Vallée A); GC (Waldmann C); Bec 1 (S.A.T. 1); Rho 1 (S.A.T. 2). Guineapigs (420-600 g.) were used as experimental animals and were inoculated by intradermal tracking of the metatarsal pads. Nagel's neurotropic mouse strain, type Vallée A (Nagel, 1937; Hofmann, 1941, 1944) was also used.

Vesicular stomatitis virus. Virus of both immunological types was used, the Ind. C and Mex 1 strains of the Indiana type and the NJ. M strain of the New Jersey type. The infectivity of virus from bovine tissue was tested on chick embryos. In most of the experiments virus strains were used which had been passaged in guinea-pigs, mice or chick embryos (7-10 days old) by the intradermal, intracerebral and chorioallantoic methods respectively. These same hosts were used in infectivity tests.

Influenza, Newcastle disease and fowl plague viruses. The PR 8 strain of influenza $A$ virus, the Lee strain of influenza $B$ virus, and the strains of Newcastle disease and fowl plague had been propagated by the allantoic method in 9- to 10-day old chick embryos. The same host and methods of inoculation were used in infectivity tests. Infection in embryos inoculated with influenza virus was determined by a fowl cell haemagglutination test of allantoic fluid collected 2-3 days after inoculation. This test was also made in experiments with the two other viruses to check the specificity of deaths of embryos. The W.S. neurotropic mouse strain of influenza $\mathbf{A}$ was also used.

Vaccinia virus. The virus was an egg-adapted strain and chick embryos aged 11-12 days were inoculated by the chorioallantoic method. 


\section{Preparation of virus suspensions}

Unless otherwise stated, virus suspensions were prepared on the day of the experiment from infective tissue freshly collected or stored for not more than a week at $4^{\circ}$. The suspending medium was $0 \cdot 15 \mathrm{M}-\mathrm{NaCl}$ adjusted to $\mathrm{pH} 7 \cdot 6$ by the addition of phosphate salts. This medium is called 'phosphate saline' and the molarity of the phosphate salts is indicated in the text. Serum, when added to the medium, was first heated to $56^{\circ}$ for $30 \mathrm{~min}$. The amount of serum added is indicated as $\%(\mathrm{v} / \mathrm{v})$.

Suspensions were prepared by grinding infective tissue in the proportion of $1 \mathrm{~g}$. to 9 or $24 \mathrm{ml}$. of suspending medium. After clarification by centrifugation the supernatant was taken as the initial virus suspension or was first filtered by negative pressure through an asbestos pad of 'Seitz $\mathrm{K}$ ' or 'Seitz EK' porosity. Such supernatants or filtrates are referred to as $1 / 10$ or $1 / 25$ tissue extracts. Gradocol membranes of $0 \cdot 6 \mu$. A.P.D. were also used to filter egg fluids or Seitz K filtrates of tissue suspensions.

All manipulations were performed on a bench in front of windows facing west. On bright days window blinds were drawn. Filter flasks were covered with a thick cloth and all glassware containing virus suspensions was kept in the dark. The light intensity to which suspensions were exposed during pipetting operations was normally about $300 \mathrm{ft}$.c. and probably never exceeded $600 \mathrm{ft} . \mathrm{c}$.

\section{Methods of exposure of virus suspensions to daylight}

Method of single dilutions. In this method a single dilution of the initial virus suspension was distributed as two $5 \mathrm{ml}$. samples in $25 \mathrm{ml}$. screw-capped bottles (McCartney pattern). One of these bottles was exposed to daylight on the laboratory bench and the other kept in the dark at the same temperature to serve as a control. The exposed bottle was immersed to a depth of about $1 \mathrm{in}$. in water in a shallow white enamelled tray, the water being maintained at room temperature or at $4^{\circ}$. At the conclusion of the period of exposure both bottles were placed in the dark at $4^{\circ}$ and were taken at once to the inoculation room where the exposed sample and then the control sample were titrated for infectivity. All dilutions were made in the same medium as that used to prepare the exposed virus suspension. Any significant difference between the infectivity titres of the two samples was an indication of the error which could arise in infectivity titrations if virus suspensions were exposed to light before the preparation of dilutions.

The standard procedure for titration was to prepare in $25 \mathrm{ml}$. screw-capped bottles tenfold dilutions of the starting material by carrying over $0.5 \mathrm{ml}$. into $4.5 \mathrm{ml}$. and mixing by gently shaking for about $5 \mathrm{sec}$. In all cases the starting material was defined as the $10^{\circ}$ dilution. A new pipette was used for each dilution and the bottles were placed at once in the dark. The set of dilutions was inoculated immediately after preparation beginning with the highest dilution, the required animals or eggs having been prepared previously. In intradermal titrations in the guinea-pig multiple tracks on both metatarsal pads were inoculated liberally. The standard volume inoculated into eggs was 
$0.1 \mathrm{ml}$. and into mice $0.03 \mathrm{ml}$. Undue exposure to light of the glass inoculating syringe was avoided. From the accumulated positive and negative observations at each dilution the $50 \%$ positive end-point dilution was calculated by the method of Reed \& Muench (1938).

Method of multiple dilutions. In this method tenfold serial dilutions of the initial virus suspension were distributed in two identical series as $5 \mathrm{ml}$. samples in $25 \mathrm{ml}$. screw-capped bottles. One series was exposed to light and the other kept in the dark as described for the method of single dilutions. At the conclusion of the period of exposure the two series of dilutions were placed in the dark at $4^{\circ}$ and were at once tested, without further dilution, by inoculation into groups of the appropriate host. The exposed series was always inoculated first. A 50\% positive end-point dilution was calculated from the host response as though the dilutions were those of a standard infectivity titration. The method of multiple dilutions was essentially an infectivity titration in which a delay occurred between preparation and inoculation of the dilutions. Exposure periods of up to $4 \mathrm{hr}$. were employed and any significant difference between the two end-point dilutions indicated inactivation due to light.

\section{Methods of exposure of virus suspensions to artificial light}

In view of the variable intensity of daylight it was essential, when comparison was to be made between different experiments, to employ a source of light of constant intensity. For this purpose the apparatus shown in PI. 1 was employed. A 250 W. compact-source mercury vapour lamp fitted with a glass window (Type M.E., obtained from the General Electric Co. Ltd.) was mounted in a sliding holder at the focus of a $10 \mathrm{~cm}$. condenser lens. A specially constructed glass exposure cell was supported centrally in the parallel beam of light at a distance of $40 \mathrm{~cm}$. from the arc. The exposure cell, which is shown to scale in horizontal section in Fig. 1, was constructed of $4 \mathrm{~mm}$. thick plates of hard glass. Each of the five cell compartments was $1 \mathrm{~cm}$. wide, $5 \mathrm{~cm}$. deep and $1.5 \mathrm{~cm}$. long in the direction of incident illumination. All surfaces of the cell not normal to the direction of incident illumination were ground to a smooth translucent finish.

The intensity of incident illumination was $3800 \mathrm{ft} . c$. and was constant to within $5 \%$ over the entire face of the cell. In some experiments the condenser lens was omitted and the position of the exposure cell was adjusted to provide an intensity of incident illumination of between 770 and $3000 \mathrm{ft} . c$. In other experiments samples of a single virus suspension were exposed simultaneously to different intensities of illumination by the attachment to the face of the cell of neutral density filters of known light transmission. This arrangement is shown in Fig. 1A. Experimental samples in the central and outside compartments of the cell were thus exposed to 100,16 and $1 \%$ of the intensity of incident illumination. Scattering of light within the cell was minimized by filling the intermediate compartments with an optically dense solution of potassium permanganate. The apparatus was set up in a darkened room or cold store in order to maintain the temperatures of exposed samples at $20^{\circ}$ or $4^{\circ}$ respectively. Heating effects due to radiation from the lamp were controlled 
by a blast of cold air directed at the face of the cell. The temperature of the exposure cell was indicated by a thermometer placed in saline in one of the compartments. The cell compartments were filled with samples of about $5 \mathrm{ml}$. and were sealed with glass cover-slips. In all cases identical control samples were held in the dark at the same temperature. At the conclusion of the period of exposure all samples were removed to $25 \mathrm{ml}$. McCartney bottles and held in the dark in iced water until required for infectivity titration. This standard procedure was equivalent to the method of single dilutions described above.

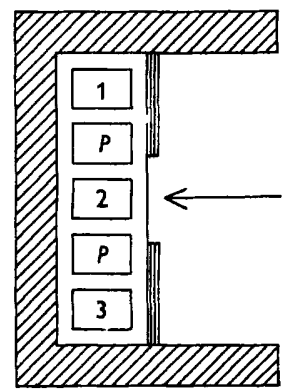

A

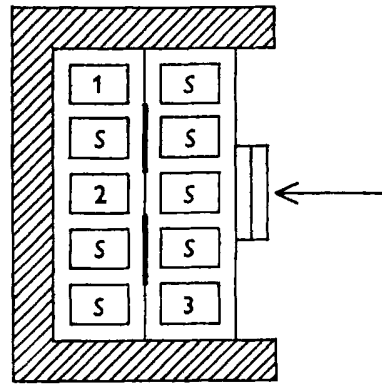

B

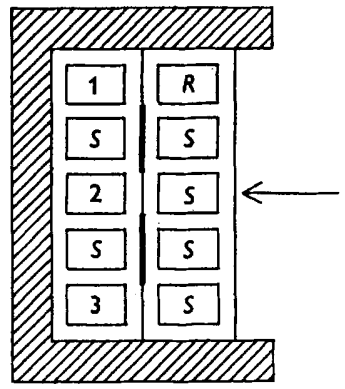

$\mathrm{c}$

Fig. 1. Schematic horizontal sections showing arrangements of exposure cells in collimated beam of artificial light. The arrows indicate the direction of the incident illumination. A, arrangement of a single cell for Expts. 7 A-C: neutral density filters attached to the face of the cell. Samples of a single virus suspension exposed to $100 \%$ of the incident intensity in the central compartment (2) and to 1 and $16 \%$ of the incident intensity in the outside compartments ( 1 and 3 ). Intermediate compartments $(P$ ) contain an optically dense solution of potassium permanganate. B, arrangement of two cells for Expt. $7 \mathrm{E}$ : sample of a single virus suspension exposed in compartment 3 to an incident intensity of $3800 \mathrm{ft} . c$. and in compartments 1 and 2 to intensities of 3100 and $2400 \mathrm{ft}$.c. obtained by the insertion into the beam of two and four additional thicknesses of glass respectively. Intermediate compartments are screened by opaque paper placed between the cells. The compartments $S$ contain phosphate saline. C, arrangement of two cells for Expt. $7 \mathrm{G}$ : virus suspensions exposed with (compartment 3) and without (compartments 1 and 2 ) the addition of $10 \%$ rabbit serum to the suspending medium. Incident illumination modified by transmission through compartments filled with phosphate saline $(S)$ or phosphate saline containing $10 \%$ rabbit serum $(R)$. Intermediate compartments are screened by opaque paper placed between the cells.

In Expts. B, D and E (Table 5), in order to employ the method of multiple dilutions, the cell was not used and the dilutions of virus suspensions were exposed in $5 \mathrm{ml}$. McCartney bottles arranged on a platform in the uncollimated beam of light.

\section{Measurement of incident light intensity}

Daylight. In the earliest experiments frequent meteorological observations were made and the average relative intensity of incident light was estimated by reference to photographic exposure tables. This scale of relative values was converted later to an absolute scale by calibration with the S.E.I. photometer (manufactured by Salford Electrical Instruments, Ltd. and distributed by Ilford Limited, Ilford, London). Such converted values are indicated in the text as approximate. Absolute determinations of incident light intensity were 
made by means of a calibrated photoelectric circuit or the S.E.I. photometer the latter instrument being the ultimate standard. When the S.E.I. photometer was employed the intensity of incident illumination was derived from the observed brightness of a standard reflecting surface placed in the required position. A sheet of clean white filter-paper of $85 \%$ reflectance was used as a convenient standard surface.

Light intensity at the laboratory bench decreased rapidly with distance from the windows. Approximate average readings obtained during the summer months (April-August) $30 \mathrm{in}$. from windows facing west, for the period 10 a.m.

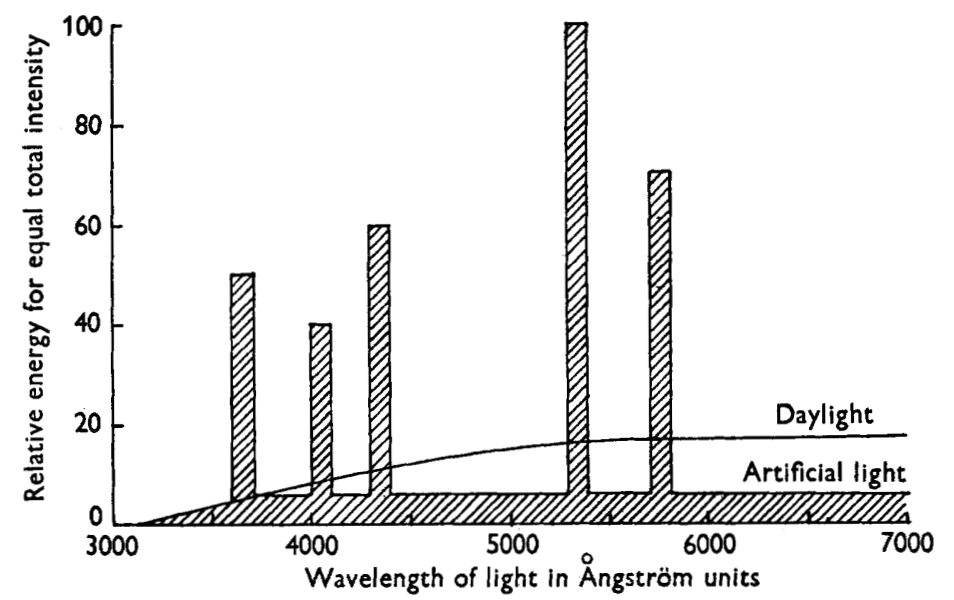

Fig. 2. A schematic representation of the spectral distributions of daylight and the light of the artificial source (shaded).

to 2 p.m., were $400 \mathrm{ft} . c$. when the sky was cloudless, and 180/300/700 ft.c. when the sky was completely overcast with low/medium/high cloud. With breaks in the cloud the intensity increased considerably and with cumulus cloud the intensity occasionally approached that of direct sunlight at about $3000 \mathrm{ft} . c$. These intensities were decreased by about $20 \%$ in the spring and autumn and by about $40 \%$ in the winter.

Artificial light. The intensity of illumination produced by the artificial source was measured either with a calibrated photoelectric circuit or with the S.E.I. photometer as described above.

Comparison of the spectral distributions of daylight and the light of the artificial source. Under the conditions defined above the artificial source produced at the exposure cell an intensity of illumination which was approximately equivalent to that of direct sunlight. The spectral qualities of the two sources, were, however, quite different. It is shown in Fig. 2 that the unmodified light from the artificial source consisted of the intense lines of the mercury spectrum superimposed upon a background of much lower intensity: the spectral distribution of sunlight is continuous. The significantly greater energy of wavelengths shorter than $4000 \mathrm{~A}$. in the artificial light was compensated, however, by the association of the artificial source with a glass lens of about $1 \mathrm{~cm}$. mean 
thickness and a cell wall of glass $4 \mathrm{~mm}$. thick. These thicknesses were such that the experimental sample contained by the exposure cell received only about a quarter of the energy of the $3600 \mathrm{~A}$. line and no energy of wavelength shorter than $3100 \mathrm{~A}$. A similar cut-off at $3100 \mathrm{~A}$. applied in the experiments in which virus suspensions were exposed to daylight transmitted by window glass and the wall of the containing bottle. It is reasonable, therefore, to conclude that any change observed following the exposure of an experimental sample to the light of the artificial source was associated with energy of those wavelengths which are present in daylight.

\section{Presentation of results}

For convenience of presentation infectivity titres are expressed as the logarithms to the base 10 of the reciprocals of the $50 \%$ end-point dilutions. Thus a $\mathbf{5 0} \%$ end-point dilution of $\mathbf{1 0}^{-\mathbf{3 . 0}}$ is expressed as an infectivity titre of 3.0. An infectivity titre of $<\mathbf{3} \cdot \mathbf{0}$ indicates an end-point dilution between $10^{0}$ and $10^{-3 \cdot 0}$. Examples of the number of animals or eggs inoculated with each dilution are given in Table 4. In all experiments the number of observations made at each dilution were such that a change of infectivity titre of one logarithmic unit may be regarded as significant. The number appearing in reference to any experiment indicates the number of the Table in which the results are presented.

\section{RESULTS}

\section{Influence of storage in the dark on the infectivity of virus suspensions}

In all of the present experiments there was an inevitable delay between the termination of exposure to light and the beginning of inoculation of test animals. During this short period the bottles containing the virus suspensions were immersed in iced water in the dark. The influence of this procedure on the infectivity of suspensions of the Ind. C and NJ. M guinea-pig strains of vesicular stomatitis virus was determined in the following two experiments. In each experiment three fivefold dilutions, including the estimated $50 \%$ end-point dilution, of an unfiltered extract of guinea-pig vesicular pad epithelium were prepared in 0.005 M-phosphate saline and were distributed in two identical sets as $10 \mathrm{ml}$. samples in $25 \mathrm{ml}$. screw-capped bottles. One set was placed at once in the dark in iced water in a closed metal container, and after $15 \mathrm{~min}$. was inoculated intradermally into guinea-pigs; eight animals were used at each dilution. The dilution bottles were returned to the metal containers immediately after the inoculation samples had been withdrawn. This procedure was repeated twice with the same dilutions at $15 \mathrm{~min}$. intervals. The second set of dilutions was inoculated twice into guinea-pigs in a similar manner after storage for 4.25 and $4.5 \mathrm{hr}$. in the dark at $4^{\circ}$.

The results are summarized in Table 1 and indicate that during storage for 15-45 min. in the dark at $4^{\circ}$ inactivation of the virus was not detected. Confidence was thus established in the routine procedure of storage of virus suspensions whilst awaiting inoculation. Over the longer periods of 4.25 and 4.5 hr. the only significant inactivation observed was that of the highest dilution in the experiment with the Ind. C strain. 
Table 1. Virus of vesicular stomatitis. Influence of storage in the dark at $4^{\circ}$ on the infectivity of minimal infective dilutions prepared in $0.005 \mathrm{M}$ phosphate saline

\begin{tabular}{|c|c|c|c|c|c|c|}
\hline & 8 & & & f stor & & \\
\hline & & $0 \cdot 25$ & 0.5 & 0.75 & $4 \cdot 25$ & $4 \cdot 5$ \\
\hline & $\begin{array}{c}\text { Dilution of } \\
1 / 25 \text { unfiltered } \\
\text { extract of guinea- }\end{array}$ & Num & $\begin{array}{r}\text { posit } \\
\text { site }\end{array}$ & $\begin{array}{l}\text { getion } \\
\text { ght g }\end{array}$ & $\begin{array}{l}\text { xteen } \\
\text { pigs }\end{array}$ & ated \\
\hline Ind. C & $10^{-8.5}$ & 9 & 7 & 9 & 4 & 0 \\
\hline & $10^{-2 \cdot 8}$ & 14 & 16 & 15 & 15 & 13 \\
\hline & $10^{-2 \cdot 1}$ & 16 & 16 & 16 & 16 & 15 \\
\hline NJ.M & $10^{-3 \cdot 8}$ & 2 & 0 & 0 & 1 & 2 \\
\hline & $10^{-3.1}$ & 4 & 4 & $\mathbf{5}$ & $\mathbf{3}$ & 2 \\
\hline & $10^{-2 \cdot 4}$ & 14 & 10 & 12 & 13 & 8 \\
\hline
\end{tabular}

In five similar experiments (3A, 3B, 3C, 5C and 5D) with the guinea-pig strains of vesicular stomatitis virus sets of dilutions were tested after $30 \mathrm{~min}$. and $4 \mathrm{hr}$. storage in the dark at $4^{\circ}$ or $20^{\circ}$. The indicated infectivity titres fell during the intervening period by $0 \cdot 4-0 \cdot 6$. In four experiments $(3 \mathrm{C}, 3 \mathrm{D}, 3 \mathrm{E}$ and $3 \mathrm{~F}$ ) performed under identical conditions with guinea-pig strains of footand-mouth disease virus there was a fall in titre of 0.4 in one experiment but no fall in the other three. These titres were based on only six to eight observations at each tenfold dilution. Individually none of these changes was therefore significant, but the consistency of the decreases in titre in experiments with the virus of vesicular stomatitis again suggested that over a period of $4 \mathrm{hr}$. in the dark minimal infective dilutions may be inactivated.

It is well to emphasize that in the experiments which form the main part of this paper the inactivation of virus suspensions due to exposure to light was estimated from the differences of infectivity between identical suspensions exposed to light and kept in the dark at the same temperature and for the same period. Thus, apart from the experiments with the viruses of vesicular stomatitis and foot-and-mouth disease discussed above, no data have been obtained on the concurrent inactivation which may occur in control suspensions during storage in the dark.

\section{Influence of exposure to daylight on the infectivity of virus suspensions}

Experiments with different strains of the virus of vesicular stomatitis obtained from various sources. Before the methods of single and multiple dilutions had been established as routine procedures three experiments were made with the Ind. $\mathrm{C}$ egg strain of vesicular stomatitis virus in which titrations of unfiltered 1/10 extracts of chorioallantoic membrane indicated infectivity titres of 6.8-7.5 when dilutions were prepared in $0.005 \mathrm{M}$-phosphate saline and inoculated immediately. The titres indicated by the same dilutions after leaving them for $1-1.5 \mathrm{hr}$. in daylight at room temperature were $1.5-1.8$ units lower. In one of these experiments a duplicate set of dilutions kept in the dark as a control indicated that the fall in titre due solely to exposure to light was $\mathbf{1 . 0}$ unit. The results of experiments with three other sources of this virus are 
detailed in Table 2, and in each instance significant decreases in infectivity titres were observed after exposure to daylight.

Table 2. Virus of vesicular stomatitis. Influence of exposure to daylight on the infectivity titre of tissue extracts. Exposure by the method of single dilutions at $4^{\circ}$

\begin{tabular}{|c|c|c|c|c|c|c|c|}
\hline \multirow[b]{2}{*}{ Strain } & \multirow[b]{2}{*}{$\begin{array}{c}\text { Infective } \\
\text { tissue }\end{array}$} & \multirow[b]{2}{*}{ Extract exposed } & \multirow{2}{*}{$\begin{array}{l}\text { Average } \\
\text { light } \\
\text { intensity } \\
\text { (ft.c.) }\end{array}$} & \multirow{2}{*}{$\begin{array}{l}\text { Period of } \\
\text { exposure } \\
\text { (hr.) }\end{array}$} & \multicolumn{2}{|c|}{ Infectivity titre } & \multirow{2}{*}{$\begin{array}{c}\text { Decrease of } \\
\text { titre due to } \\
\text { exposure }\end{array}$} \\
\hline & & & & & Control & Exposed & \\
\hline Ind. $\mathrm{C}$. & Mouse brain & $\begin{array}{l}1 / 10,000 \text { in } 0.005 \mathrm{M}- \\
\text { phosphate saline, } \\
\text { unfiltered }\end{array}$ & $\sim 1800$ & $3 \cdot 5$ & $\mathbf{2 \cdot 2}$ & Inactive & $\geqslant \mathbf{2 \cdot 7}$ \\
\hline Mex. 1 & $\begin{array}{l}\text { Bovine tongue } \\
\text { epithelium }\end{array}$ & $\begin{array}{l}1 / 25 \text { in Hartley's } \\
\text { digest broth filtered } \\
0.6 \mu . \text { A.P.D. mem- } \\
\text { brane }\end{array}$ & $\sim 400$ & 6 & $5 \cdot 1$ & $2 \cdot 8$ & $2 \cdot 3$ \\
\hline NJ. M & $\begin{array}{l}\text { Guinea-pig pad } \\
\text { epithelium }\end{array}$ & $\begin{array}{l}1 / 25 \text { in } 0.005 \mathrm{M} \text {-phos- } \\
\text { phate saline filtered } \\
0.6 \mu . \text { A.P.D. mem- } \\
\text { brane }\end{array}$ & $\sim 240$ & 6 & $4 \cdot 4$ & $1 \cdot 1$ & $\mathbf{3 \cdot 3}$ \\
\hline
\end{tabular}

Comparative experiments with the viruses of vesicular stomatitis and foot-andmouth disease. In the standard procedures employed at this institute for the infectivity titration of foot-and-mouth disease virus in guinea-pigs no special precautions are taken to eliminate exposure of the virus suspensions to indirect sunlight. The incident light intensity is decreased considerably, however, by the racks in which the sets of dilutions are held. In hot weather these racks are immersed in iced water in an open metal container. All sets of dilutions are prepared in the laboratory before taking them to the animal units for inoculation. Protective rubber clothing is always worn in these units and the time taken to change involves a delay of at least $10 \mathrm{~min}$. between completion of the manipulations in the laboratory and the beginning of inoculation. When comparative titrations of twelve samples are undertaken at one time the necessary manipulations involve a delay between preparation and inoculation of each series of dilutions which increases from $1 \mathrm{hr}$. for the first series to $2 \mathrm{hr}$. for the twelfth. There has been no indication that exposure to daylight for up to $2 \mathrm{hr}$. under these conditions has any significant influence on the infectivity titre of suspensions of the virus of foot-and-mouth disease. This same standard procedure was adopted with guinea-pig strains of vesicular stomatitis virus until dilutions of egg strains of this virus were observed to be unstable unless kept in the dark. A comparison of the stability of guinea-pig strains of the viruses of vesicular stomatitis and foot-and-mouth disease was then made in experiments which are summarized in Table 3. The inoculation of four identical sets of dilutions was delayed by storage in the dark for $30 \mathrm{~min}$. and for $4 \mathrm{hr}$. at $4^{\circ}$, and in daylight for $4 \mathrm{hr}$. at $4^{\circ}$ and at $20^{\circ}$. The changes which occurred in the control suspensions stored in the dark have already been discussed.

In only one of the four experiments with foot-and-mouth disease virus was there a significant decrease of infectivity titre caused by exposure to daylight. 
In this experiment (3D) the estimated intensity of illumination was the greatest of the series and included several bright periods. In experiment $3 \mathrm{C}$, where the two viruses were exposed simultaneously, the greater stability of the virus of foot-and-mouth disease was demonstrated clearly. It is apparent that in the routine titration procedure adopted with foot-and-mouth disease virus exposure to daylight is without significant influence on the infectivity titre even if all manipulations are carried out at $20^{\circ}$.

Table 3. Viruses of vesicular stomatitis and foot-and-mouth disease. Influence of exposure to daylight on the infectivity of dilutions of unfiltered extracts of guinea-pig pad epithelium prepared in 0.04M-phosphate saline. Exposure by the method of multiple dilutions at $4^{\circ}$ and $20^{\circ}$

\begin{tabular}{|c|c|c|c|c|c|c|c|c|}
\hline \multirow[b]{3}{*}{ Expt. } & \multirow[b]{3}{*}{ Virus } & \multirow[b]{3}{*}{ Strain } & \multirow{3}{*}{$\begin{array}{c}\text { Average } \\
\text { light } \\
\text { intensity } \\
\text { (ft.c.) }\end{array}$} & \multirow{3}{*}{$\begin{array}{c}\text { Period of } \\
\text { exposure } \\
\text { (hr.) }\end{array}$} & \multicolumn{3}{|c|}{$\begin{array}{l}\text { Infectivity titre } \\
\text { indicated by }\end{array}$} & \multirow{3}{*}{$\begin{array}{l}\text { Decrease of } \\
\text { titre due to } \\
\text { exposure } \\
\text { at } 4^{\circ}\end{array}$} \\
\hline & & & & & \multirow{2}{*}{$\begin{array}{c}\text { Control } \\
\text { dilutions } \\
4^{\circ}\end{array}$} & \multicolumn{2}{|c|}{$\begin{array}{l}\text { Exposed } \\
\text { dilutions }\end{array}$} & \\
\hline & & & & & & $4^{\circ}$ & $20^{\circ}$ & \\
\hline $\mathbf{A}$ & $\begin{array}{l}\text { Vesicular } \\
\text { stomatitis }\end{array}$ & NJ. M & $\sim 300$ & $\begin{array}{l}0.5 \\
4\end{array}$ & $\begin{array}{l}4 \cdot 9 \\
4 \cdot 4\end{array}$ & $\leqslant 2 \cdot 1$ & $\leqslant 2 \cdot 1$ & $\geqslant 2 \cdot 3$ \\
\hline B & & NJ. M & $\sim 400$ & $\begin{array}{l}0 \cdot 5 \\
4\end{array}$ & $\begin{array}{l}4 \cdot 6 \\
4 \cdot 2\end{array}$ & $\mathbf{3} \cdot \mathbf{0}$ & $2 \cdot 2$ & $1 \cdot 2$ \\
\hline $\mathbf{C i}$ & & Ind. C & $\sim 240$ & $\begin{array}{l}0.5 \\
4\end{array}$ & $\begin{array}{l}4 \cdot 6 \\
4 \cdot 2\end{array}$ & $2 \cdot 2$ & $1 \cdot 2$ & $\mathbf{2 \cdot 0}$ \\
\hline Cii & $\begin{array}{l}\text { Foot-and- } \\
\text { mouth disease }\end{array}$ & GC & $\sim 240$ & $\begin{array}{l}0.5 \\
4\end{array}$ & $\begin{array}{l}4.6 \\
4 \cdot 8\end{array}$ & 4.2 & 4.5 & $0 \cdot 6$ \\
\hline $\mathbf{D}$ & & GB & $\sim 600$ & $\begin{array}{l}0.5 \\
4\end{array}$ & $\begin{array}{l}4 \cdot 3 \\
4 \cdot 5\end{array}$ & $\mathbf{3} \cdot \mathbf{3}$ & $3 \cdot 4$ & $1 \cdot 2$ \\
\hline $\mathbf{E}$ & & 1 & $\sim 240$ & $\begin{array}{l}0 \cdot 5 \\
4\end{array}$ & $\begin{array}{l}4 \cdot 6 \\
4 \cdot 6\end{array}$ & $4 \cdot 6$ & $4 \cdot 4$ & 0.0 \\
\hline $\mathbf{F}$ & & 1 & $\sim 180$ & $\begin{array}{l}0 \cdot 5 \\
4\end{array}$ & $\begin{array}{l}4 \cdot 3 \\
3 \cdot 9\end{array}$ & $\mathbf{3 \cdot 6}$ & 3.9 & $0 \cdot 3$ \\
\hline
\end{tabular}

In the three experiments with vesicular stomatitis virus the $4 \mathrm{hr}$. period of exposure to daylight at $4^{\circ}$ caused decreases in the indicated infectivity titres from 1.2 to $\geqslant 2 \cdot 3$ units. In Expts. $3 \mathrm{~B}$ and $3 \mathrm{C}$ the titres indicated by the dilutions exposed at $20^{\circ}$ were about 1.0 unit lower than those indicated by the dilutions exposed at $4^{\circ}$, but there were no dark controls at the higher temperature. In Expt. 3A the sets of dilutions stored in the dark for $4 \mathrm{hr}$. at $4^{\circ}$ and exposed to daylight for $4 \mathrm{hr}$. at $20^{\circ}$ were also tested by inoculation of chick embryos and the respective titres were $\geqslant 5 \cdot 1$ and $\leqslant 2 \cdot 1$.

In two similar experiments $(5 \mathrm{~A}$ and $\mathbf{5} \mathrm{C})$ with the guinea-pig strains of the virus of vesicular stomatitis the dilutions were prepared from filtrates and were exposed at $20^{\circ}$ only. Infectivity titres were reduced by at least $2 \cdot 0$ units following exposure for $4 \mathrm{hr}$. In Expt. $5 \mathrm{C}$ the indication was that on bright days an exposure period of only $1 \mathrm{hr}$. might produce a significant reduction of infectivity titre. With this virus the phenomenon of inactivation by exposure to light could clearly lead to false interpretations unless appropriate precautions were taken. 


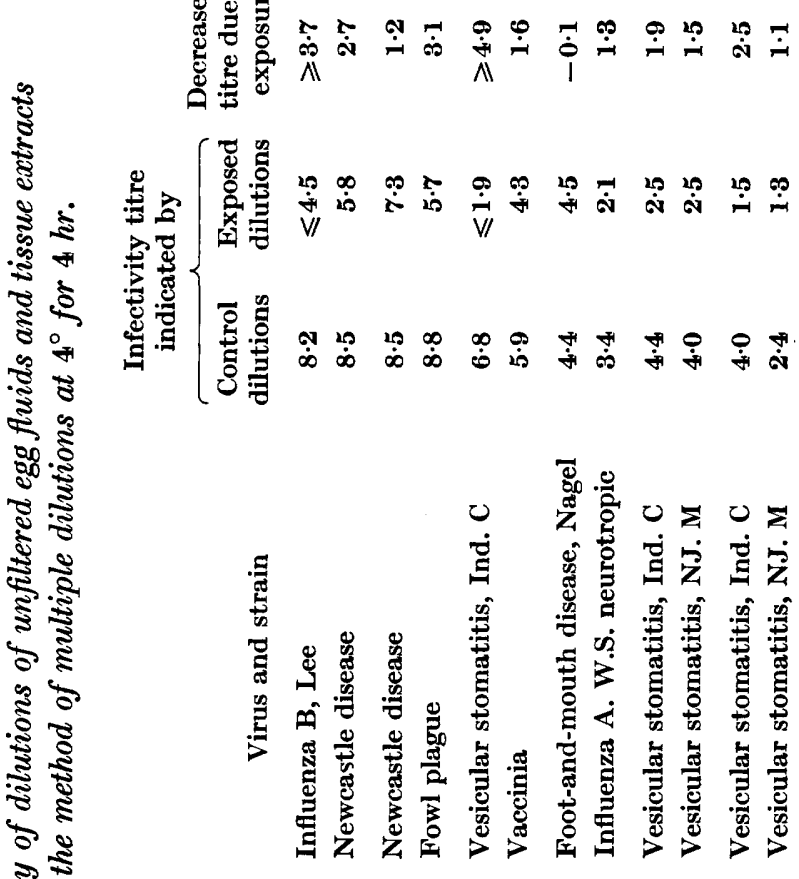

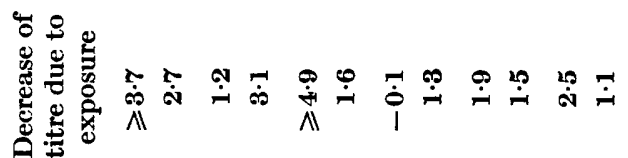


Experiments with the viruses of influenza, Nervcastle disease, forw plague and vaccinia. Table 4 contains the results of experiments in which several viruses were exposed to daylight at $4^{\circ}$ by the method of multiple dilutions. A valid comparison of two viruses was made in each experiment by using identical sources of infective tissue and suspending medium. A significant inactivation due to exposure to daylight occurred with egg strains of the viruses of influenza B, Newcastle disease, fowl plague and vaccinia. In the experiment comparing neurotropic strains of the viruses of foot-and-mouth disease and influenza A significant inactivation occurred only with the latter virus and to a degree comparable with that observed with the neurotropic strains of the virus of vesicular stomatitis.

\section{Influence of exposure to artificial light on the infectivity of virus suspensions}

Experiments with guinea-pig strains of the virus of vesicular stomatitis

(a) Comparison of daylight and artificial light. In two experiments $(5 \mathrm{C}$ and 5D) made on consecutive days the decrease of the infectivity of virus suspensions caused by exposure to daylight was compared with that caused by artificial light of the same intensity. Portions of epithelium from the same guinea-pig pads were used in both experiments and the incident intensity of artificial light in Expt. 5D was adjusted to correspond with that of the daylight in Expt. 5C. The results indicated that within the limits of significance

Table 5. Virus of vesicular stomatitis. Influence of exposure to daylight or artificial light on the infectivity of dilutions of filtered $(0 \cdot 6 \mu$.) $1 / 25$ extracts of guinea-pig pad epithelium prepared in 0.04M-phosphate saline. Exposure in bottles by the method of multiple dilutions at $20^{\circ}$

\begin{tabular}{|c|c|c|c|c|c|c|c|}
\hline \multirow[b]{2}{*}{ Expt. } & \multirow[b]{2}{*}{$\begin{array}{l}\text { Virus } \\
\text { strain }\end{array}$} & \multirow[b]{2}{*}{$\begin{array}{l}\text { Source of } \\
\text { light }\end{array}$} & \multirow[b]{2}{*}{$\begin{array}{c}\text { Light } \\
\text { intensity } \\
\text { (ft.c.) }\end{array}$} & \multirow[b]{2}{*}{$\begin{array}{c}\text { Period of } \\
\text { exposure } \\
\text { (hr.) }\end{array}$} & \multicolumn{2}{|c|}{$\begin{array}{l}\text { Infectivity titre } \\
\text { indicated by }\end{array}$} & \multirow[b]{2}{*}{$\begin{array}{l}\text { Decrease of } \\
\text { titre due to } \\
\text { exposure }\end{array}$} \\
\hline & & & & & $\begin{array}{l}\text { Control } \\
\text { dilutions }\end{array}$ & $\begin{array}{l}\text { Exposed } \\
\text { dilutions }\end{array}$ & \\
\hline $\mathbf{A}$ & NJ. M & Daylight & 780 & 4 & $\mathbf{2 \cdot 6}$ & $\leqslant 0 \cdot 1$ & $\geqslant 2.5$ \\
\hline B & NJ. M & Artificial & 2700 & $\begin{array}{l}2 \\
4\end{array}$ & $2 \cdot 2$ & $\begin{array}{l}\leqslant 0 \cdot 5 \\
\leqslant 0 \cdot 5\end{array}$ & $\geqslant 1.7$ \\
\hline C & Ind. $C$ & Daylight & 1300 & $\begin{array}{l}0.5 \\
1 \\
2 \\
4\end{array}$ & $2 \cdot 6$ & $\begin{array}{r}2.0 \\
1.6 \\
1 \cdot 1 \\
\leqslant 0.1\end{array}$ & $\geqslant \mathbf{2} \cdot \mathbf{0}$ \\
\hline D & Ind. $\mathrm{C}$ & Artificial & 1300 & $\begin{array}{l}0 \cdot 5 \\
1 \\
2 \\
4\end{array}$ & $3 \cdot 0$ & $\begin{array}{r}2 \cdot 1 \\
1 \cdot 1 \\
1 \cdot 0 \\
\leqslant 0 \cdot 1\end{array}$ & $\geqslant 2.3$ \\
\hline $\mathbf{E}$ & Ind. $\mathbf{C}$ & Artificial & 2700 & 0.5 & $2 \cdot 9$ & $\leqslant 1 \cdot 6$ & $\geqslant 1 \cdot 3$ \\
\hline
\end{tabular}

In Expts. A, B and E duplicate sets of dilutions prepared with $1 \%$ guinea-pig serum added to the diluent were exposed simultaneously. In Expts. $B$ and $E$ there were also sets with $5 \%$ guinea-pig serum added. In all cases the control dilutions indicated an infectivity titre which varied by only $\mathbf{0 . 2}$ unit or less from those shown above for the dilutions with no serum added. All the exposed dilutions were inactivated to the same extent as those with no serum added with the single exception of those with $5 \%$ serum in Expt. $\mathrm{E}$ which indicated a titre of $\mathbf{2} \cdot \mathbf{0}$. 
equal intensities of illumination by either source produced the same decreases in infectivity. A similar comparison of the two sources of light was made in Expt. 6D. The decrease of the infectivity titre was again of the same magnitude in both cases.

(b) Filtration as a factor influencing susceptibility to inactivation. In five experiments $(6 \mathrm{D}-6 \mathrm{H})$ virus suspensions were prepared from unfiltered extracts of guinea-pig pad epithelium and were exposed to light at $4^{\circ}$. The decrease of infectivity was less than might have been anticipated from the results of other experiments $(5 \mathrm{~B}, 5 \mathrm{D}, 5 \mathrm{E}$ and $6 \mathrm{~A})$ in which suspensions were prepared from filtered extracts and were exposed to light at $19-20^{\circ}$. This suggested that inactivation due to exposure to light was influenced either by the filtration of the initial extract or by the temperature. Results with other strains of this virus indicated that filtration was probably the major factor. If the effect produced by filtration were due only to the removal of particulate matter greater than a certain size then it should be possible to produce the same effect by an equivalent centrifugation procedure. An investigation was made of the influence of such a procedure and of the molarity of the phosphate salts.

A 1/6.25 extract of guinea-pig pad epithelium infected with the NJ. M strain of virus was prepared in 0.04 $\mathrm{M}$-phosphate saline. By further dilution in 0.04 $\mathrm{M}$ phosphate saline, and in saline alone, two $1 / 50$ extracts were prepared. These were termed the $0.04 \mathrm{M}$ - and the $0.005 \mathrm{M}$-phosphate saline 'low-speed supernatants' respectively. A $50 \mathrm{ml}$. sample of the $0.005 \mathrm{M}$-phosphate saline lowspeed supernatant was clarified further by high-speed centrifugation sufficient to remove particles of a diameter greater than about $0 \cdot 1 \mu$. From this supernatant, a sample of $35 \mathrm{ml}$. was withdrawn and termed the 'high-speed supernatant'. A $14 \mathrm{ml}$. sample of the high-speed supernatant was filtered through a $0 \cdot 6 \mu$. A.P.D. gradocol membrane $(4 \mathrm{~cm}$. diameter) which, in the absence of an adsorption effect, would remove no further particles from the high-speed supernatant. A similar sample was also filtered through a Seitz EK pad $(3 \mathrm{~cm}$. diameter). Each of the five suspensions obtained in this way was diluted once in its own buffer to give a 1/100 suspension which was exposed in the cell for $4 \mathrm{hr}$. at $4^{\circ}$ to a light intensity of $3800 \mathrm{ft} . c$. The suspensions were added to the cell as they became available and in this way it was possible to titrate all exposed samples and the dark controls immediately after the period of exposure. The results are given below:

Suspensions
$0 \cdot 04 \mathrm{M}$-phosphate saline low-speed supernatant
$0 \cdot 005 \mathrm{M}-$-phosphate saline low-speed supernatant
$0 \cdot 005 \mathrm{M}$-phosphate saline high-speed supernatant
High-speed supernatant filtered $0 \cdot 6 \mu$ membrane
High-speed supernatant filtered Seitz EK pad

$\begin{array}{cc}\text { Infectivity titre } \\ \text { Control } & \text { Exposed } \\ \mathbf{3 . 5} & \mathbf{2 . 6} \\ 4.0 & \mathbf{2 . 9} \\ \mathbf{3 . 5} & \mathbf{2 . 4} \\ \mathbf{3 . 4} & \mathbf{1 . 3} \\ \text { Inactive } & \text { Inactive }\end{array}$

Decrease in titre due to exposure

$0 \cdot 9$

$1 \cdot 1$

$1 \cdot 1$

$2 \cdot 1$

The non-infectivity of the Seitz EK filtrate was not unexpected in view of the absence of $50 \%$ Hartley's digest broth from the suspending medium. The decrease of the infectivity titres was the same in the three unfiltered suspensions but was significantly greater in the suspension prepared from the Gradocol 


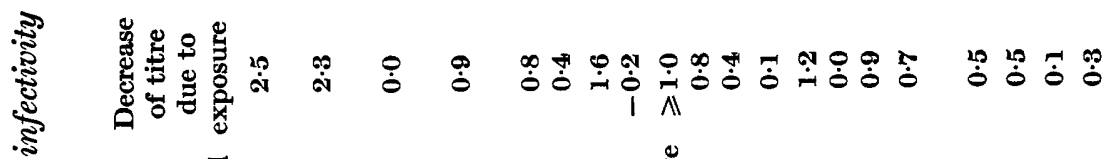

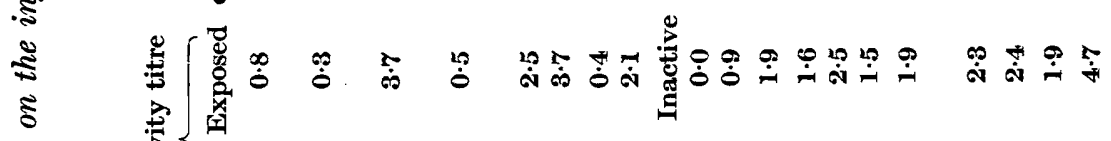

:

. స్తి

离 용

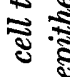
.

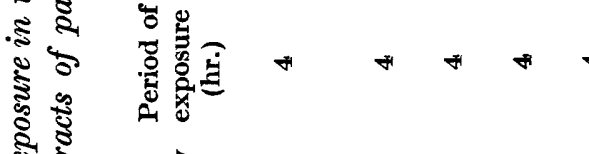

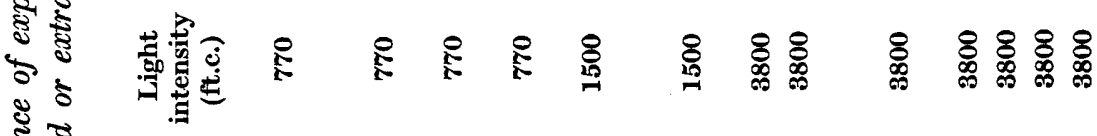
芯芯

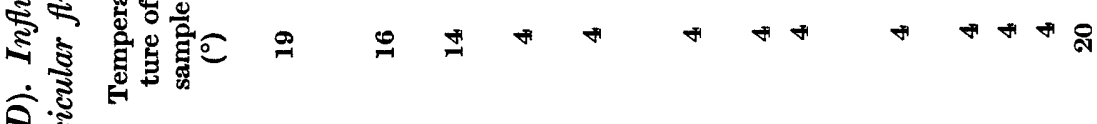

ลิ

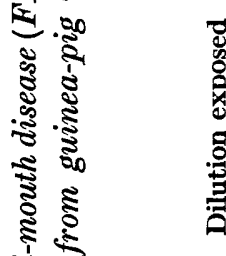
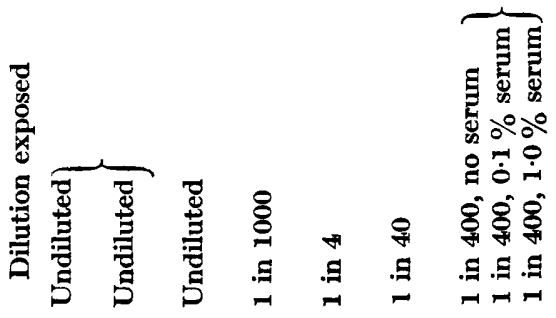

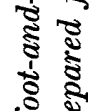

है है

ริ

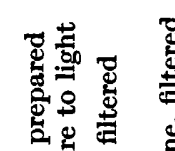

总

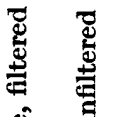

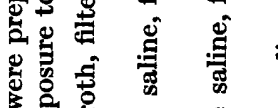

हूँ

है के

క్

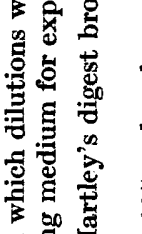

घ: 夏

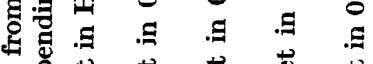

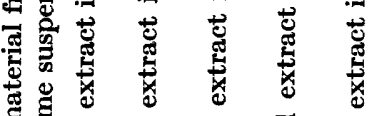

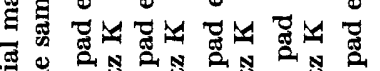

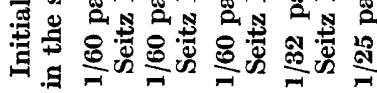

兽

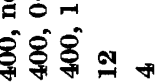

$. \Xi . \Xi . \Xi$

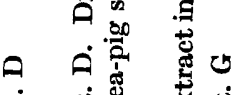

蒙 客要

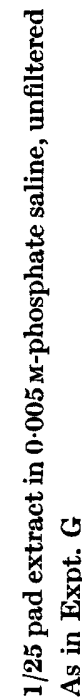

$\dot{0}$

离

.5

目亭

유

.

密

菅

㱐

$+\frac{1}{5}$

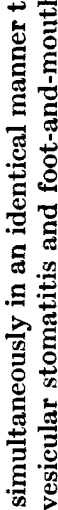

잉

宊

究

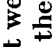

$+\frac{1}{80}$

光

e

递

क क

讯

है?

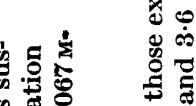

喿政

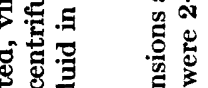



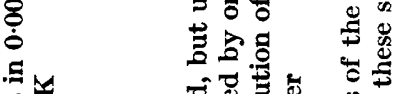

告

胥

5.

要

ะี้

造

보

(1)

式重

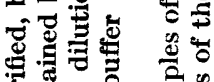

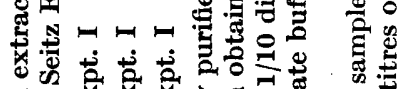

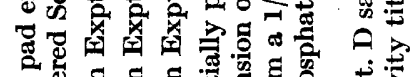

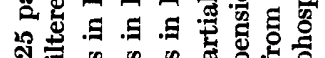


membrane filtrate of the high-speed supernatant. These results suggest that in the course of filtration an adsorption process is largely responsible for the removal of a protective agent.

\section{Experiments with guinea-pig strains of the virus of foot-and-mouth disease}

To compare the susceptibilities of the viruses of foot-and-mouth disease and vesicular stomatitis suspensions were exposed under identical conditions in separate experiments $(6 \mathrm{~A}, 6 \mathrm{~B}$ and $6 \mathrm{C})$ or simultaneously in the same experiment $(6 \mathrm{D}$ and $6 \mathrm{E})$. To provide as severe a test as possible in further experiments $(6 \mathrm{I}-6 \mathrm{M})$ with the virus of foot-and-mouth disease the initial extracts were either filtered through a Seitz EK pad or purified by ultra-centrifugation. Suspensions were then exposed to the maximum intensity of illumination for $4 \mathrm{hr}$. For the titrations in Expts. 6I-6 L five-fold dilutions were prepared and ten guinea-pigs were inoculated with each dilution. Under these conditions the observed decreases of infectivity titre of 0.5 and 0.7 unit may be regarded as significant. Greater decreases than these were always observed with suspensions of the virus of vesicular stomatitis prepared from extracts of guineapig pad epithelium even when these extracts were unfiltered and were exposed in lower dilutions under the same or less severe conditions. In Expt. 6M, in which extraneous proteins were largely removed by a single cycle of ultracentrifugation, the resuspended deposit suffered no significant loss of infectivity on exposure to light. In another experiment a similarly purified suspension obtained by two cycles of ultracentrifugation was exposed to a daylight intensity of $350 \mathrm{ft} . c$. for $4 \mathrm{hr}$. at $4^{\circ}$ and the infectivity titres of the control and exposed samples were $\mathbf{5 \cdot 3}$ and $5 \cdot 1$ respectively. These data confirm that the virus of foot-and-mouth disease is relatively resistant to inactivation by exposure to light.

\section{Experiments with egg strains of the viruses of Newcastle disease and influenza}

A pool of unfiltered amniotic fluid from 9-day-old chick embryos infected with the virus of Newcastle disease was used, after storage for 4 weeks at $4^{\circ}$, in an experiment to compare two suspending media; (i) $0.005 \mathrm{M}$-phosphate saline; (ii) a filtrate $(0 \cdot 6 \mu)$ of normal amniotic fluid collected from 10-day-old chick embryos. Equivalent 1/3200 suspensions in each medium were exposed simultaneously for $4 \mathrm{hr}$. at $4^{\circ}$ to an incident illumination of $3800 \mathrm{ft}$.c. The decrease of titre of $\geqslant 3.2$ and $\geqslant 2.8$ units, respectively, revealed no difference between the natural medium and the phosphate saline as suitable diluents for the virus. The same material was used 2 weeks later in Expt. $7 \mathrm{C}$ and a similar result was obtained.

In experiments with the viruses of influenza the suspending medium was 0.005 M-phosphate saline. Single dilutions prepared from unfiltered allantoic fluid (Lee strain) after storage for 2-4 weeks at $4^{\circ}$ were exposed at $4^{\circ}$ to $3800 \mathrm{ft} . c$. Dilutions of $1 / 100,1 / 50,000$ and 1/100,000 were exposed for $30 \mathrm{~min}$.; the infectivity titres were decreased by $1 \cdot 0,0.8$ and 1.0 units, respectively. In a similar experiment with the PR 8 strain a 1/10,000 dilution fell in titre 
by 1.9 units after exposure for $1 \mathrm{hr}$. A greater degree of inactivation was observed in two experiments with the Lee strain when a single filtrate $(0 \cdot 6 \mu$. A.P.D. membrane) of allantoic fluid was used after storage for 2 and 6 weeks. In these experiments samples of a 1/10,000 dilution were exposed simultaneously at $4^{\circ}$ to $3800 \mathrm{ft}$.c. and $600 \mathrm{ft}$.c. in a cell with a neutral density filter attached. The suspension exposed to the higher intensity of illumination was removed after $x$ min. and then stored for $5 x$ min. in the dark. Exposure of the second suspension to one-sixth of this intensity was continued for a total of $6 x \mathrm{~min}$. to make the product of the intensity and duration of exposure the same for the two suspensions. The results were:

\begin{tabular}{|c|c|c|c|c|}
\hline \multirow[b]{2}{*}{ Expt. } & \multirow[b]{2}{*}{$\begin{array}{l}\text { Time } x \\
\text { (min.) }\end{array}$} & \multicolumn{3}{|c|}{$\begin{array}{l}\text { Infectivity titre and, where end-point was not } \\
\text { bracketed, infection ratio in eggs inoculated with } \\
\text { undiluted sample }\end{array}$} \\
\hline & & $\begin{array}{l}\text { Dark } \\
\text { control }\end{array}$ & $\begin{array}{l}\text { Exposed to } \\
3800 \text { ft.c. }\end{array}$ & $\begin{array}{l}\text { Exposed to } \\
600 \mathrm{ft} . \mathrm{c}\end{array}$ \\
\hline 1 & 40 & $3 \cdot 5$ & $<0 \cdot 0,1 / 6$ & $<0 \cdot 0,1 / 6$ \\
\hline 2 & $\begin{array}{l}10 \\
20\end{array}$ & $1 \cdot 6$ & $\begin{array}{l}1 \cdot 3 \\
<0 \cdot 0,1 / 7\end{array}$ & $\begin{array}{l}0.5 \\
<0.0,3 / 7\end{array}$ \\
\hline
\end{tabular}

These results are not inconsistent with the hypothesis that the decrease of infectivity of a virus suspension by exposure to light is determined by the product of the intensity and the duration of exposure.

\section{The influence of various factors on susceptibility to inactivation by exposure to light}

It has already been shown that filtration is a factor which may influence the susceptibility of a virus suspension to inactivation by exposure to light. The influence of the following factors was also studied.

Incident light intensity. In Expts. 7 A-7 E, despite the different susceptibilities of suspensions prepared under different conditions, it was observed in all cases that inactivation increased regularly with the intensity of incident light. Inactivation was relatively greater at the lower intensities of illumination.

In Expt. 7D an increase of the incident light intensity from $770 \mathrm{ft.c.}$ to $3800 \mathrm{ft} . c$. by the insertion of the collimating lens caused the fall of the infectivity titre to increase from 1.0 to 3.0 units. The observation of this greater inactivation, despite the insertion of a lens of $1 \mathrm{~cm}$. average thickness, implied that a residual low intensity of ultraviolet light from the artificial source was not a major factor in the mechanism of inactivation. In Expt. $7 \mathrm{E}$ the incident light intensity was modified by the insertion of additional thicknesses of glass as shown in Fig. 1 B. With $8 \mathrm{~mm}$. of glass interposed in the collimated beam the incident intensity was reduced from 3800 to $3100 \mathrm{ft}$.c. The observed decreases of infectivity titre indicated that, if ultraviolet light alone was responsible for inactivation, consideration must be limited to the range of near ultraviolet wavelengths between 3300 and $4000 \mathrm{~A}$. since energy of shorter wavelengths was reduced by at least $95 \%$ by transmission through $8 \mathrm{~mm}$. of the glass. 
The addition of certain agents to the suspending medium. There have been many reports of the loss of infectivity of suspensions of viruses following storage for a short period at room temperature. The risk of errors being introduced into infectivity titrations by this instability has been minimized in some laboratories by the use of diluents containing $10 \%$ mammalian serum, or more recently, $0 \cdot 2 \%$ bovine albumin (Dick \& Taylor, 1949). Wilson (1946) used undiluted sheep serum to stabilize the infectivity of suspensions of the virus of louping-ill.

The stabilizing action of $10 \%$ serum on the infectivity of virus suspensions exposed to light was demonstrated strikingly in an experiment in which a suspension of chorioallantoic membrane infected with virus of the Ind. C egg strain of vesicular stomatitis was diluted serially in two equivalent sets using as diluents $0.005 \mathrm{M}$-phosphate saline with and without the addition of $10 \%$ rabbit serum. Samples of each dilution were exposed simultaneously by the method of multiple dilutions under the conditions of Expt. 4C. The infectivity titres indicated by the control and exposed dilutions were 6.8 and $\leqslant 1.9$ in the absence of serum and $7 \cdot 2$ and 6.8 in the presence of serum. Thus the decrease of the indicated titre in the absence of serum was at least 4.0 units greater than in its presence. In Expts. 5 A, $5 \mathrm{~B}, 5 \mathrm{E}$ and $6 \mathrm{~F}$ suspensions of the same virus were prepared with 1 and $5 \%$ guinea-pig serum added and only in Expt. $6 \mathrm{~F}$ was there any suggestion of stabilization of infectivity.

Further demonstration of the value of $10 \%$ serum was obtained in Expt. 7 F in which the decrease of titre was at least 4.1 units in the absence of serum but was only 0.3 unit and 1.2 units when $10 \%$ rabbit serum and $10 \%$ guinea-pig serum respectively were present in the suspending medium. Similar protection against inactivation was afforded both when the guinea-pig serum was not inactivated and when it was reconstituted from a freeze-dried sample. The nature of the protective action of serum was investigated further in Expt. 7 G where the results suggested that the protective action of serum occurred only when the serum was mixed with the virus suspension and that modification of the incident light by transmission through serum was not the determining factor.

In view of the observation that the infectivity of the virus of equine encephalomyelitis was stabilized by the addition of $1 \mathrm{mg}$. cysteine hydrochloride/ml. to the suspending medium (Labzoffsky, 1946) the value of this agent was tested in the case of vesicular stomatitis virus. In an experiment made simultaneously with Expt. 3B four sets of multiple dilutions were prepared to which this amount of cysteine hydrochloride was added, followed by readjustment to $\mathrm{pH} \mathbf{7 \cdot 6}$. The results were in every case the same as those obtained without this reducing agent and indicated no protective action.

Temperature of virus suspensions during exposure. In Expt. $7 \mathrm{H}$ there was no significant difference between the decrease of titre observed following exposure at $4^{\circ}$ and $20^{\circ}$.

Storage of the initial virus suspension at $4^{\circ}$. A comparison of the results of Expt. 7I with those of Expts. 7 A and 7B showed a wide variation in the decrease of infectivity of filtrates of amniotic fluid exposed under identical 


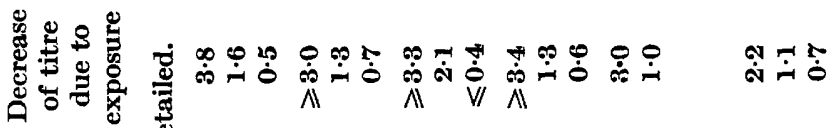

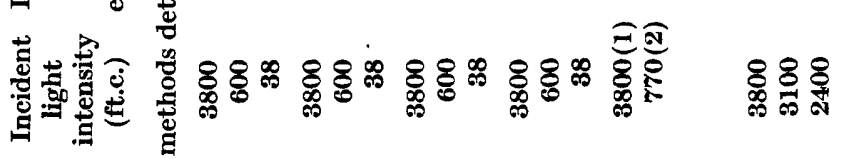

:

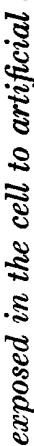





.



है.

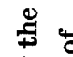

.

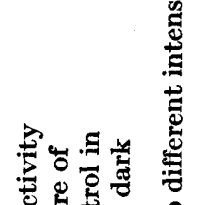
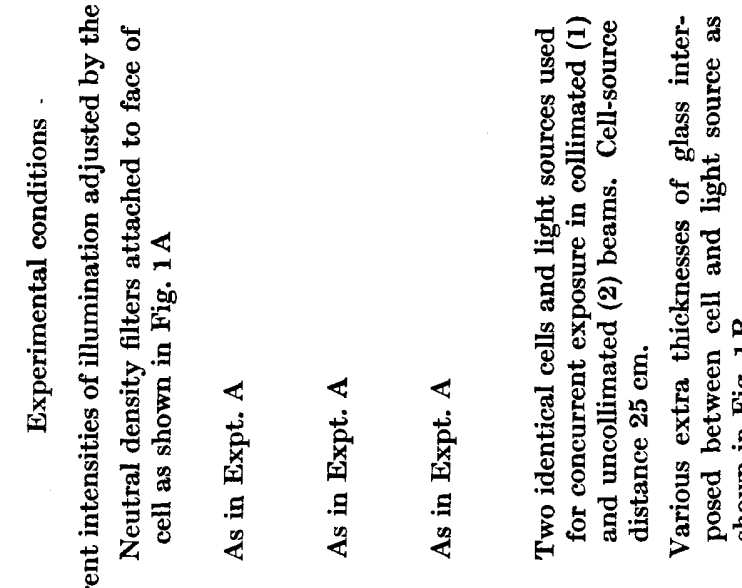

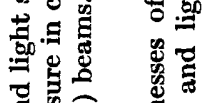

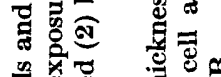

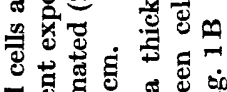

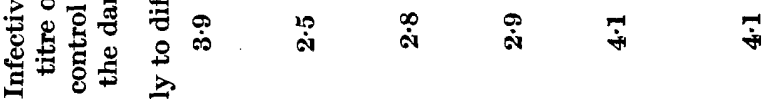

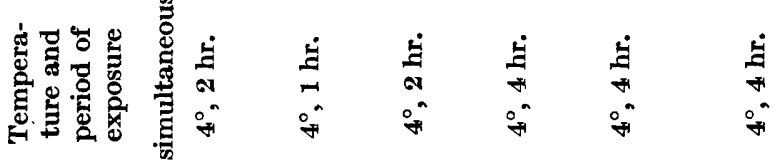

$\$$

:

ร

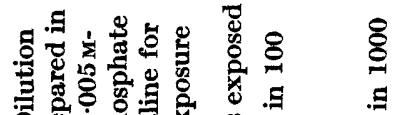

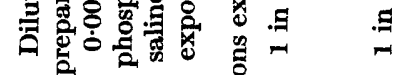

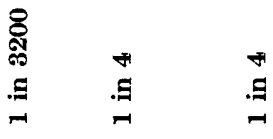

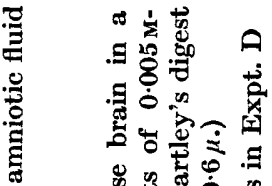

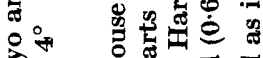

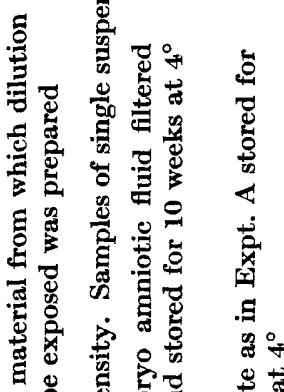

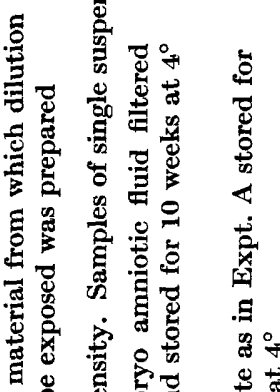

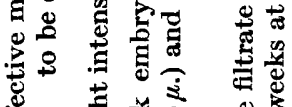

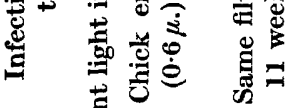

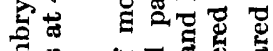

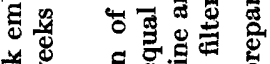

势

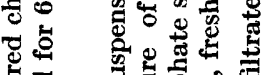

要

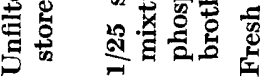

$\frac{0}{2}$

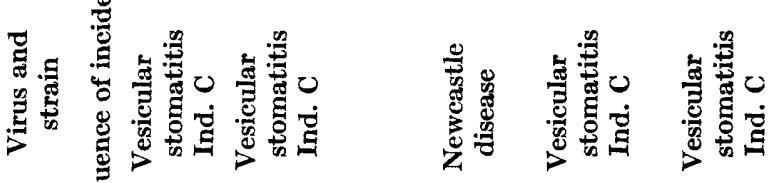
家鸹

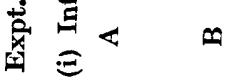

a

지 


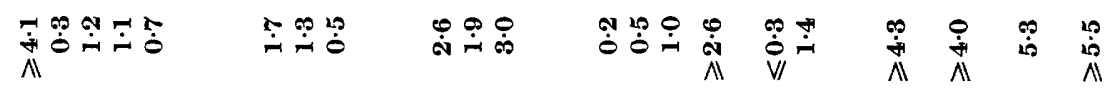

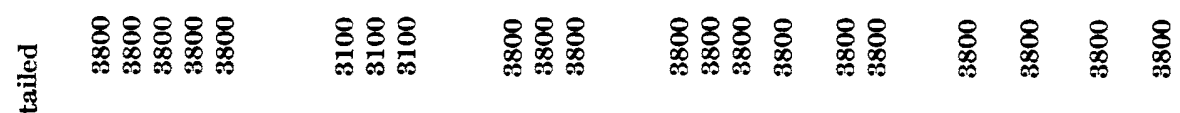

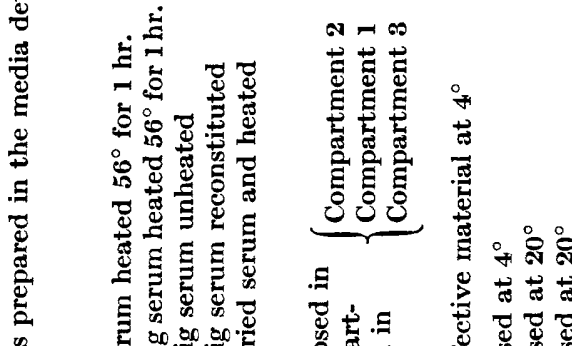

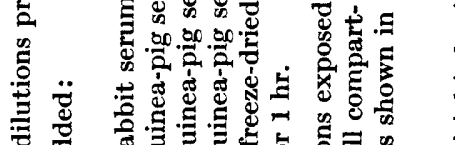

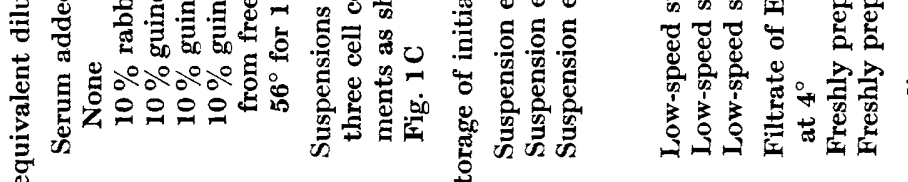

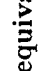

宁

छ

总

宓苛。

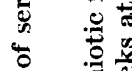

:

㟡

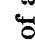

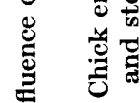

党

$\approx$

官

$\because$

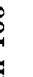

$\stackrel{2}{\circ}$

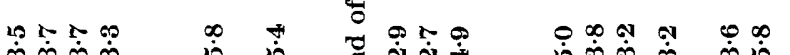

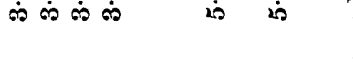

ט.

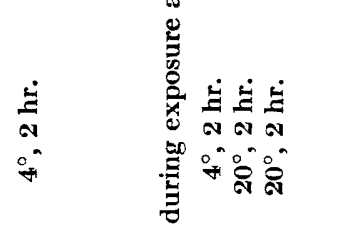

象

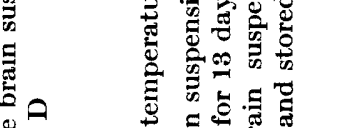

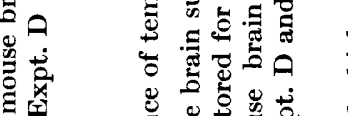

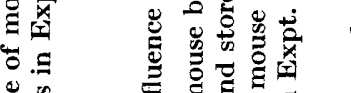

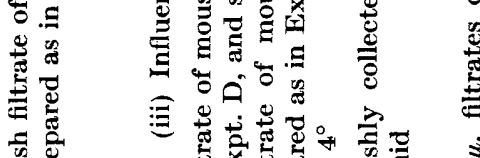

蜜唁

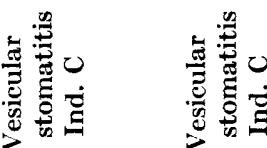

苋

है

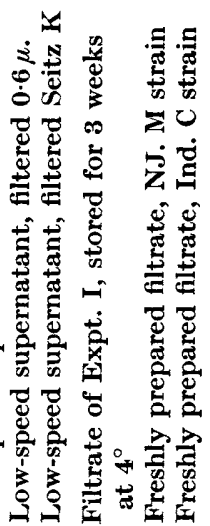

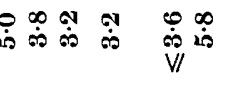

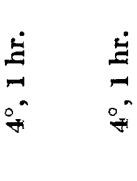

$\stackrel{8}{:}$

है है

के

总
多荧

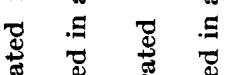

远

$\checkmark \pm$

ส छี ซี

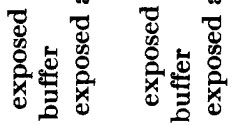

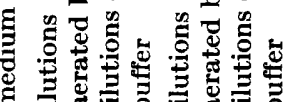

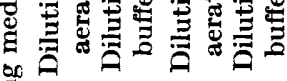

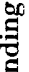

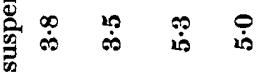
प

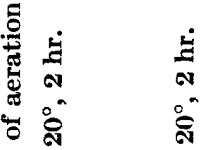

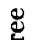

8ह 8

..

¿ -

递范

壱思

ชนึ้

苯。虽

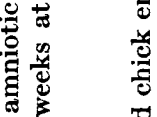

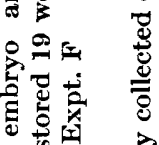

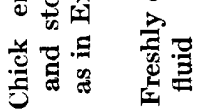

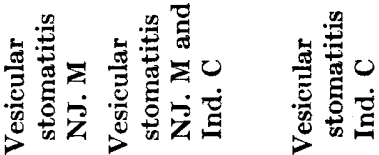


conditions. Two factors possibly contributing to this result were the virus strain used and the period of storage of the filtrate. These factors were investigated in Expt. 7J in which the filtrate of Expt. 7I was used again after a period of storage during which there was no significant change of infectivity. Exposure under the same conditions as before, however, now caused a decrease of titre which was at least $2 \cdot 1$ units greater. The decrease in titre of suspensions prepared from fresh filtrates of either strain and exposed simultaneously again did not exceed $\mathbf{1 \cdot 4}$ units. This suggested that dilutions of freshly prepared filtrates of infective amniotic fluid were less susceptible to inactivation by exposure to light than those of filtrates stored for a period at $4^{\circ}$. A comparison of the results of Expts. $7 \mathrm{D}$ and $7 \mathrm{H}$ with a single filtrate of mouse brain suspension also suggested that susceptibility to inactivation was greater after storage. It was apparent, however, from the results obtained in Expt. $7 \mathrm{H}$ at $20^{\circ}$ that different fresh filtrates might differ in their susceptibility to inactivation.

Degree of aeration of the suspending medium. An uncontrolled factor which might have contributed to different results in separate experiments was the degree of aeration of the suspending medium. The greater susceptibility of filtered suspensions might also have been due to a decrease in the amount of dissolved gas following filtration by negative pressure. In Expt. $7 \mathrm{~K}$ a comparison was made between two samples of freshly autoclaved phosphate saline. One of these was saturated with air by shaking and the other was not exposed to the air before use. These two diluents were used to prepare the exposed suspensions and the dilutions for the subsequent titrations. The magnitude of the observed decreases of titre demonstrated the extreme susceptibility of some suspensions even when prepared from fresh material. There was, however, no indication that the degree of aeration of the diluent was a significant factor in the mechanism of inactivation.

\section{DISCUSSION}

The aim in this investigation was to determine whether a significant decrease of infectivity occurred when virus suspensions were exposed for relatively short periods to the intensities of visible light normally experienced in the laboratory. Although significant inactivation was demonstrated under these conditions the data obtained indicated that many factors influenced the extent to which suspensions of a given virus might be inactivated. When consideration is limited to a single strain of one virus, known factors which influence the susceptibility to inactivation are the source of infective tissue and the method of preparation and storage of the initial suspension. It is doubtful whether other investigators have considered exposure to light as a factor contributing to the instability of the infectivity of virus suspensions prepared in protein-free media. The authors are unaware of any other investigations in which direct comparisons have been made between the infectivity of virus suspensions placed in light and in darkness.

Although in the present studies it has been shown that serum is of value in maintaining the infectivity of suspensions of vesicular stomatitis virus in the presence of light, there are many instances, particularly in physical-chemical 
Journal of General Microbiology, Vol. 10, No. 3

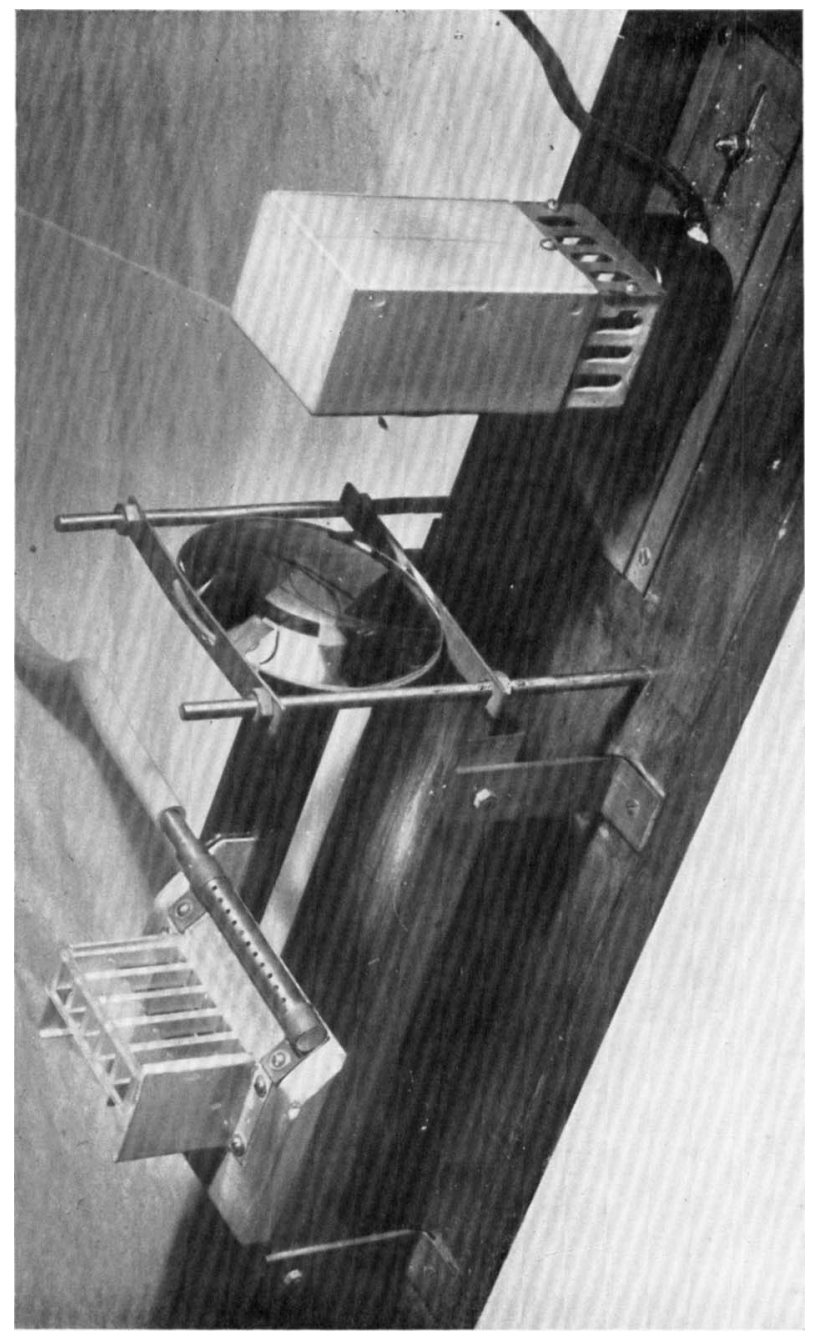

H. H. Skinner \& C. J. Bradish-InaCtivation of virus suspensions by light. Plate 1 
studies, in which it is required to concentrate and purify specific components and in which the addition of extraneous non-dialysable materials is inadmissible. Other studies at this institute of the virus system of vesicular stomatitis (Bradish, Brooksby \& Dillon, unpublished) have shown that it is possible to conduct all manipulations of virus suspensions in rooms illuminated only by photographic safe lights. In this way inactivation by exposure to light is minimized at every stage of the experimental procedure and a quantitative recovery of infectivity may be achieved.

The exact wavelengths to which suspensions of a given virus may be most susceptible have not been investigated. In the experiments with the artificial source of light the effects observed were produced by exposure to light of those wavelengths which are normally present in daylight after passage through glass. The results of the experiments in which the incident light intensity was modified by transmission through additional thicknesses of glass indicated that residual low intensities of ultraviolet light were not a major factor. Further elucidation of the mechanism of the inactivation of virus suspensions by exposure to light requires detailed investigation of the susceptibility of individual virus systems to radiation of defined wavelengths and consideration of the possibility that inactivation may be due to indirect rather than to direct action.

Acknowledgement is due to the Veterinary Laboratory, Ministry of Agriculture and Fisheries, Weybridge, for the viruses of Newcastle disease and of fowl-plague, to the Lister Institute of Preventive Medicine, Elstree, for the virus of vaccinia and to our colleague Dr W. M. Henderson for the strains of influenza virus which he obtained from The Children's Hospital, Philadelphia. Nagel's strain of foot-andmouth disease virus was received from Prof. Levaditi, Institut Alfred Fournier, Paris.

It is a pleasure to acknowledge the technical assistance of $\mathrm{Mr} \mathbf{E}$. H. Knight.

\section{REFERENCES}

Dick, G. W. A. \& TAYlor, R. M. (1949). Bovine plasma albumin in buffered saline solution as a diluent for viruses. J. Immunol. 62, 311.

HofmanN, W. (1941). Weitere Untersuchungen über den Neurotropismus des Maulund Klauenseuchevirus. Zbl. Bakt. (1. Orig.), 148, 69.

Hofman,, W. (1944). Mitteilung über weitere Versuche mit dem bei der Maus neurotropen Stamm B des Maul- und Klauenseuchevirus. Zbl. Bakt. (1. Orig.), 151, 161.

LABZOFFSKY, N. A. (1946). Effect of reducing agents on the viability of equine encephalomyelitis virus (Eastern type). Canad. J. Res. 24, 119.

NAGEL, H. C. (1937). Untersuchungen über das Verhasten des Maul- und Klauenseuchevirus im Zentralnervensystem kleiner Versuchtiere. Dtsch. tierärztl. Wschr. 45, 624 .

Reed, L. T. \& Muench, H. (1938). A simple method of estimating 50 per cent endpoints. Amer. J. Hyg. 27, 493.

Wilson, D. R. (1946). Studies in Louping-ill: III. Louping-ill antiserum. J. comp. Path. 56, 78.

\section{EXPLANATION OF PLATE}

The apparatus employed for the exposure of virus suspensions to the light of the artificial source. Components from right to left: artificial source of light, condenser lens of $10 \mathrm{~cm}$. diameter, cold air blower, exposure cell of five compartments. 